\title{
Poezja (wobec) Zagłady - ku nowym narracjom
}

Wiedzą już, gdzie nas nie ma - wszędzie dlatego zewsząd wywołują śmiało, wierszami nas wołają, ojczyznami, imprezami, festiwalami.

Więc nie róbmy zawodu (sobie też) i bądźmy.

P. Matywiecki: $P o^{1}$

Jak dotąd w polskim literaturoznawstwie nie powstała spójna, przekrojowa synteza poezji (wobec) Zagłady. Nie oznacza to jednak, że wyrazista narracja na ten temat, w kilku dających się wyodrębnić wariantach, nie funkcjonuje od dawna w rodzimej humanistyce. Ma ta narracja w zasadzie charakter obiegowy i dlatego jest niewystarczająca - wiele spraw nie tyle fałszuje, ile symplifikuje i generalizuje. Oto pewien szczególny paradoks, który wyznacza ramy problemowe i konceptualne piątego numeru „Narracji o Zagładzie”. Dla określenia naszego punktu wyjścia istotna zdaje się jeszcze jedna prawidłowość, polegająca na badawczej praktyce swoiście negatywnego wydzielenia poezji, prace mające charakter przeglądowy bądź monograficzny zdecydowanie częściej dotyczą bowiem wyłącznie prozy lub literatury dokumentu osobistego ${ }^{2}$, utworom poe-

${ }^{1}$ P. Matywiecki: Po. W: Tenże: Widownia. Kraków 2012, s. 91.

2 Por. np. J. WróBel: Tematy żydowskie w prozie polskiej 1939-1987. Kraków 1991; B. KRUPA: Opowiedzieć Zagładę. Polska proza i historiografia wobec Holocaustu (1987-2003). Kraków 2013; A. Ubertowska: Holokaust. Auto (tanato) grafie. Warszawa 2014; S. BuryŁa: Wokót Zagłady. Szkice o literaturze Holokaustu. Kraków 2016 (a także wcześniejsze książki tego autora); A. MACH: Świadkowie świadectw. Postpamięć zagłady w polskiej literaturze najnowszej. Toruń 2016. 
tyckim, jeśli już o nich mowa, poświęca się znacznie mniej miejsca te proporcje rozkładają się w tomach zbiorowych ${ }^{4}$. Skutkuje to oczywiście dość specyficznym sprofilowaniem obrazu polskiej literatury Holokaustu ${ }^{5}$, gdyż najważniejsze, najbardziej nośne ustalenia na jej temat tworzy się, pomijając poezję, i niekoniecznie chodzi o to, że uprzywilejowane są wówczas pewne kategorie interpretacyjne, a raczej o to, jak się nimi operuje, o ich wpływ na presupozycje dobór materiału czy egzemplifikacji. Niewykluczone bowiem, że gdyby właśnie wiersze umieścić w centrum niektórych koncepcji, uległyby one interesującej

${ }^{3}$ Por. np. A. Ubertowska: Świadectwo - trauma - głos. Literackie reprezentacje Holokaustu. Kraków 2007 (rozdz. Tożsamość jako ślad kryptograficzny. (Holokaust w późnych poematach Tadeusza Różewicza); Negocjowanie przeszłości. (O kilku wierszach Adama Zagajewskiego); Popioły, analepsis); K. ADA mCZy K: Doświadczenia polsko-żydowskie w literaturze emigracyjnej (1939-1980). Kraków 2008 (rozdz. Wstyd antysemity (po latach). Przypadek Jerzego Pietrkiewicza; Nieprzekładalne doświadczenia. Poeci o Zagładzie; Antynostalgia i nostalgia. Rzecz o wygnaniu); M. Cuber: Metonimie Zagłady. O polskiej prozie lat 1987-2012. Katowice 2013 (rozdz. Gry w Zagładę. O poezji i prozie Radosława Kobierskiego i Agnieszki Kłos); B. PrzymuszaŁa: Smugi Zagłady. Emocjonalne $i$ konwencjonalne aspekty tekstów ofiar i ich dzieci. Poznań 2016 (rozdz. „Skaza żydowskości”problem tożsamości etnicznej w tekstach z czasów Zagłady ( $z$ antologii Borwicza); Negatywy. Poezja Różewicza wobec Zagłady; Wiersze Wata o Zagładzie - wizja jako rodzaj świadectwa). Pewien wyjątek stanowią tu rekonesansowe artykuły, w których właściwie nie różnicuje się tekstów poetyckich i prozatorskich: W. PAnAs: Zagłada od Zagłady. Szoah w literaturze polskiej. W: TenżE: Pismo i rana. Studia i szkice o literaturze polskiej. Lublin 1996, s. 91-117; H. Grynberg: Holocaust w literaturze polskiej. W: TenżE: Prawda nieartystyczna. Wołowiec 2002, s. 141-182. Podobną strategię przyjmuje też Karolina FAMUlSKA-Ciesıelska w książce w dużej mierze poświęconej Zagładzie: Polacy - Żydzi - Izraelczycy. Tożsamość w literaturze polskiej w Izraelu. Toruń 2008. Z kolei Irena Maciejewska jako autorka ważnego hasła Getta doświadczenie w literaturze polskiej (w: Słownik literatury polskiej XX wieku. Red. A. Brodzka, M. Puchalska, M. Semczuk, A. Sobolewska, E. Szary-Matrwiecka. Wrocław 1992, s. 331-338) wprawdzie oddzielnie omawia poezję i prozę, zaznacza jednak ich równorzędność. Por. I. Macıejewska: [Wprowadzenie]. W: Męczeństwo i Zagłada Żydów w zapisach literatury polskiej. Wybór, oprac. i wprowadzenie I. Maciejewska. Warszawa 1988, s. 5-33. Osobne, wręcz zbyt eksterytorialne, miejsce w tym obszarze problemowym zajmuje, w przeważającej mierze nieprzyswojona w kanonie i w powszechnej świadomości, literatura polsko-żydowska, także ta tworzona w jidysz, w badaniach nad którą nierzadko wyodrębnia się poezję i ją dowartościowuje, a dla której Zagłada jest często punktem dojścia. W tej perspektywie pilnego spełnienia domaga się postulat scalenia pól i kierunków refleksji nad literaturą Holokaustu.

${ }^{4}$ Por. Literatura polska wobec Zagłady. Red. A. Brodzka-Wald, J. Leociak, D. KrawCZyŃska. Warszawa 2000; Stosowność i forma. Jak opowiadać o Zagładzie? Red. M. GıowiŃski, K. Chmielewska, K. Makaruk, A. Molisak, T. Żunowski. Kraków 2005; Pamięć Shoah. Kulturowe reprezentacje i praktyki upamiętnienia. Red. A. ZeIdler-JaniszewsKa, T. Majewski, M. Wójcik. Łódź 2009; Ślady obecności. Red. S. BuryŁA, A. Molisak. Kraków 2010; Zagłada. Wspótczesne problemy rozumienia i przedstawiania. Red. P. Czapliński, E. Domańska. Poznań 2009; Ślady drugiej wojny światowej i Zagłady w najnowszej literaturze polskiej. Red. B. SIENKIEwiCZ, S. Karolak. Poznań 2016.

${ }^{5} \mathrm{Na}$ temat tego konstruktu por. A. UBertowska: Świadectwo - trauma - głos..., s. 19-23; D. Krawczyńska: Wstęp. W: Literatura polska wobec Zagłady (1939-1968). Red. S. BuryŁA, D. KrawCZyńsKa, J. LeOciak. Warszawa 2013, s. 18-19. 
modyfikacji. Uprawnione wydaje się więc podejrzenie, że za sprawą praktyki dominującej w literaturoznawczych studiach nad Zagładą poezja jest zwykle zawłaszczana, podporządkowywana, zamiast być włączaną do dyskursu. Tak przedstawiający się - oczywiście w pewnym uproszczeniu - stan badań bardziej skłania do stawiania problemów i pytań, kreślenia projektów oraz perspektyw niż do formułowania diagnoz czy podsumowań.

Przede wszystkim warto choćby pokrótce przyjrzeć się trzem bardzo różnym książkom ${ }^{6}$, które - każda na swój sposób - mierzą się z wyzwaniem syntetycznego ujęcia tego zagadnienia, ponieważ pozwalają domyślić się przyczyn powstania owej luki, wskazują na trudności oraz - pośrednio - perspektywy zasługujące na podjęcie. W pierwszej kolejności przywołać trzeba - dziś już pod pewnymi względami anachroniczną - pracę Natana Grossa Poeci i Szoa...7, opublikowaną niemal trzy dekady temu, wówczas w pewnej mierze przełomową. Zresztą ta propozycja, wymagająca wprawdzie różnorakich uzupełnień, wciąż bardzo wiele znaczy jako gest wyodrębnienia doświadczenia Zagłady w refleksji poetyckiej oraz dowartościowania twórczości autorów i autorek identyfikujących się z tożsamością żydowską, choć nie są oni jedynymi bohaterami tej książki, której kompozycję wyznacza porządek portretów - na każdy rozdział przypada jeden głos. Uprzywilejowanie perspektywy jednostkowej sprawia wszelako, że zaciera się znaczenie pewnych szerszych zjawisk, a zarazem różnice między rangą poszczególnych twórców i ich dzieł zdają się niewystarczająco zaakcentowane.

Przed podobnym problemem stanął Piotr Matywiecki jako autor poświęconej poezji części kompendium Literatura polska wobec Zagłady (1939-1968)8 . Konstruując ambitną, możliwie najszerszą panoramę tekstów, zdecydował się na przyjęcie porządku tematyczno-problemowego, który to klucz dopełnił szkicami o kilkorgu wyróżnionych postaciach (wybranych może nadto arbitralnie, gdy pomyśleć o nazwiskach pominiętych). Jest to nadal bezprecedensowy i imponujący pod względem rozległości zebranego materiału przegląd twórczości poetów znanych oraz zupełnie zapomnianych. Matywiecki wyraźnie podkreśla - co szczególnie istotne w kontekście okresu, jakim się zajmuje - dokumentalny wymiar wierszy ${ }^{9}$, niewykluczone, że w ten sposób chce dowieść równorzędnej pozycji poezji w stosunku do innych form. Ponieważ obszerne opracowanie

${ }^{6} \mathrm{~W}$ tym kontekście trzeba przynajmniej odnotować studium, które nie rozwinęło się w obszerniejszą publikację: L. Neuger: Żydzi w powojennej poezji polskiej. W: Tenże: Pomysły do interpretacji. Studia i szkice o literaturze polskiej. Kraków 1997.

7 N. Gross: Poeci i Szoa. Obraz Zagłady Żydów w poezji polskiej. Sosnowiec 1993.

${ }^{8}$ P. Matrwiecki: Poezja. W: Literatura polska wobec Zagłady (1939-1968)..., s. 174-240, 301-403. Por. B. Krupa: Monumentalna monografia. „Teksty Drugie” 2015, nr 4, s. 231-234; K. Kuczyńska-Koschany: Polska literatura Zagłady. Odsłona pierwsza: 1939-1968. „Poznańskie Studia Polonistyczne. Seria Literacka” 2015, nr 25, s. 351-361.

${ }^{9}$ Por. podobne ujęcie R. Löwa: Uwagi do przyszłej historii literatury (polskiej) o Zagładzie. W: Literatura polska wobec Zagłady..., s. 71-87. 
obejmuje zaledwie trzydzieści lat - od początku II wojny światowej do cezury roku 1968 - tym dobitniej uświadamia ono skalę zjawiska, które przecież w następnych dekadach jeszcze się rozrastało i komplikowało. Ten projekt ze wszech miar zasługuje na uznanie i kontynuację w dwóch kolejnych tomach zapowiedzianych przez redaktorów kompendium, także dlatego, że może prowadzić do podjęcia szczegółowych studiów nad twórczością dotąd marginalizowaną. Niemniej pewien poznawczy niedosyt wzbudza swoiście podręcznikowy charakter wykładu Matywieckiego przybierającego postać komentarzy do obszernych cytatów. Takie skupienie autora na detalu sprawia, że konkluzje mogą zdawać się niedostatecznie wyraziste czy uspójnione. Niewątpliwie podejmowane kwestie wymagają pogłębienia, wypracowania bardziej zaawansowanych kategorii opisu, wywiedzionych choćby z kręgu zagadnień nowej humanistyki (o tego rodzaju potencjale świadczy na przykład cząstka pt. Zagłada $i$ natura, pozbawiona jednak nieantropocentrycznego horyzontu historii środowiskowej), ale przede wszystkim na systematyczne ujęcie zasługiwałoby zjawisko w gruncie rzeczy najbardziej elementarne, wręcz immanentne, a zarazem swoiście tu pomijane, czyli wpływ Zagłady na języki poetyckie ${ }^{10}$.

$\mathrm{W}$ takim razie należy wreszcie wymienić opublikowaną $\mathrm{w}$ tym samym roku co kompendium Literatura polska wobec Zagłady (1939-1968) monografię Katarzyny Kuczyńskiej-Koschany „Bсе поэты жиды“. Antytotalitarne gesty poetyckie $i$ kreacyjne wobec Zagłady oraz innych doświadczeń granicznych ${ }^{11}$. Jej książka sytuowałaby się na przeciwnym biegunie, gdyż autorka przekornie odpowiada na wyzwanie syntezy - podejmując je i zarzucając. Tylko jedno spośród studiów składających się na tę pracę ma charakter przeglądowy (Słowa do ciszy. Poetyki Shoah $w$ liryce polskiej. Rekonesans ${ }^{12}$ ) - badaczka skupiła się w nim na materii językowej, na konturze wierszy, poczyniła próbę opisania nurtów i tendencji dających się wyodrębnić w poezji o Zagładzie, która musiała poetyckość zredefiniować, niekiedy jej właściwie zaprzeczyła. Charakteryzując te radykalne przemiany, literaturoznawczyni uznaje je za konsekwencje niezgody na definitywne zamilknięcie, niemotę, twierdzi, że wiersze na swój sposób tworzą przestrzeń rezonansu, są nierzadko wyrazem obezwładniającej bezradności. $Z$ tej perspektywy kategoria niewyrażalności - uchodząca często za przebrzmiałą - okazuje

${ }^{10}$ Bezspornie ważnym punktem odniesienia winna stać się tu praca Piotra Mitznera: Biedny język. Szkice o kryzysie słowa i literaturze wojennej (Warszawa 2011), która z jednej strony dotyka szerszego zjawiska, bo literatury wojennej, z drugiej dotyczy ograniczonego wycinka czasowego, choć autor oczywiście świadom jest dalszych konsekwencji diagnozowanego problemu.

${ }^{11}$ K. Kuczyńska-Koschany: „Bce nоэты жиды“. Antytotalitarne gesty poetyckie i kreacyjne wobec Zagłady oraz innych doświadczeń granicznych. Poznań 2013. Por. A. Juchniewicz: „Bunt się uczula”. Katarzyna Kuczyńska-Koschany: „Bсе поэты жиды“. Antytotalitarne gesty poetyckie $i$ kreacyjne wobec Zagłady oraz innych doświadczeń granicznych. Poznań, Wydawnictwo Naukowe UAM, 2013, ss. 360. „Narracje o Zagładzie” 2016, nr 2, s. 307-317.

${ }^{12}$ K. KucZyŃsKa-Koschany: „Bсе nоэты жиды“ “.., s. 245-260. 
się nadal operacyjna. W pozostałych partiach monografii Kuczyńska-Koschany nie rozwinęła jednak swych dociekań w pokrewnych kierunkach, czym dała do zrozumienia, że bardziej interesują ją innego rodzaju ujęcia (a niewykluczone też, że zdradziła, iż powątpiewa w sens budowania syntezy). Ostatecznie bowiem skoncentrowała się na szerzej pojętej żydowskości kulturowej wyrażającej się w nieledwie uniwersalnej figurze obcego oraz przyjmującej postać kategorii opisowej pozwalającej zorganizować myślenie o dość dużym wycinku poezji (i nie tylko). W rezultacie autorka wskazała na nieoczywiste oddziaływanie Zagłady pojmowanej jako „wydarzenie przekształcające” ${ }^{13}$. Z pewnością ta ostatnia sprawa - niebezpośrednich odniesień funkcjonujących poza płaszczyzną tematyczną - warta jest dalszego eksplorowania.

Już z tego dość skrótowego rekonesansu jasno wynika, że style pisania o poezji Zagłady, a zwłaszcza samo zagadnienie syntezy i jej (aproksymatywne) realizacje, wymagałyby osobnego krytycznego studium ${ }^{14}$, swoiście metatematycznego, zorientowanego metodologicznie (do rozważenia pozostaje między innymi konieczność podejmowania dyskusji z Berelem Langiem i dawania odporu jego radykalnym tezom ${ }^{15}$ ), stawiającego pytania w zasadzie fundamentalne o tryb wywodu - raczej odtwórczy czy twórczy, propedeutyczny, powtarzający i porządkujący utrwalone rozpoznania czy osadzony w bardziej zaawansowanych studiach nad Zagładą i poezją. Następnie nasuwa się kwestia wewnętrznej periodyzacji liryki na tle prób systematyzowania przemian literatury Holokaustu ${ }^{16}$ oraz ich powiązań z cezurami politycznymi. Dalej istotne wydaje się, aby wyłaniające się różne kryteria typologiczne (tożsamościowo-chronologiczne, tematyczne, estetyczne) odpowiednio zhierarchizować, by krzyżując się ze sobą, wzajemnie się dopełniały. Od razu więc narzuca się pytanie o sposób korzystania z całego

13 Tamże, s. 14-15. Por. P. CzApliński: Zagłada jako wyzwanie dla refleksji o literaturze. „Teksty Drugie” 2004, nr 5, s. 9-22.

14 Analogicznie - sygnalizuje Matywiecki (Poezja..., s. 233-234) - na osobną uwagę zasługiwałyby antologie poezji Zagłady powstałej podczas wojny: Pieśń ujdzie cało... Antologia wierszy o Żydach pod okupacją niemiecką. Wstęp i oprac. M.M. Borwicz. Warszawa-Łódź-Kraków 1947; Izrael w poezji polskiej. Antologia. Wybór J. Winczakiewicz. Paryż 1958; Poezja Polski walczqcej 1939-1945. Antologia. Wybór J. Szczawiej. T. 1-2. Warszawa 1974. Co ciekawe, Matywiecki nie wymienia najwcześniejszego podziemnego zbioru $Z$ otchłani (Red. J. WAjdelota. Warszawa 1944). Na szczególnych prawach do tego wyliczenia można by jeszcze dopisać wielojęzyczną antologię: Słowa pośród nocy. Poetyckie dokumenty Holokaustu. Wstęp, wybór i oprac. A. Żó£kiewska. Przeł. M. Tuszewicki, A. ŻóŁkiewska, M. Koktysz. Warszawa 2012. Por. J. Hensel: Ofiary $i$ świadkowie. Wiersze czasu wojny jako źródło wiedzy o Zagładzie. W: Literatura polska wobec Zagłady..., s. 51-71.

15 B. LAng: Przedstawianie zła: etyczna treść a literacka forma. Przeł. A. ZięBińska-Witek. „Literatura na Świecie” 2004, nr 1-2, s. 15-65. Por. H. White: Poetyka pisarstwa historycznego. Przeł. E. Domańska, M. Loba, A. Marciniak, M. Wilczyński. Red. E. Domańska, M. WilCZyŃsKi. Kraków 2010. Zob. K. CHMIELEWsKa: Literackość jako przeszkoda, literackość jako możliwość wypowiedzenia. W: Stosowność i forma..., s. 21-33.

16 Por. M. GŁowiński: Wielkie zderzenie. „Teksty Drugie” 2002, nr 3, s. 201, 208-211. 
rozległego materiału - bezkompromisowo, niemal rezygnując z selekcji (byłby to casus Matywieckiego), czy w siatce egzemplifikacji. W następstwie należałoby rozstrzygnąć, co z kolei wynika w związku z lekturą monografii Kuczyńskiej-Koschany, jak szeroko winno się pojmować formułę poezji (wobec) Zagłady. Ta parenteza, pozornie oczywista, wyznacza właściwie koncepcyjne spektrum rozciągające się między bezpośrednimi odniesieniami, zapisami doświadczeń, pamięci, wizji a trudną (czasami niemożliwą) do jednoznacznego uchwycenia aurą, objawiającą się niekiedy nawet nie w aluzjach, lecz wyłącznie w kondycji języka. To spektrum rozciąga się także między spontaniczną twórczością amatorów a wybitnymi dziełami autorów świadomych skali wyzwania, z jakim się mierzą.

Wprawdzie na gruncie polskim nigdy nie odbyła się dyskusja na miarę sporu Paula Celana $\mathrm{z}$ Theodorem W. Adornem ${ }^{17}$, sporu, w następstwie którego trwale ustaliła się poznawcza ranga poezji jako równoprawnej partnerki dociekań filozoficznych. W naszym kręgu językowym recepcja tej debaty przebiegała w innym kierunku niż w humanistyce niemieckojęzycznej i nie poskutkowała metodologicznymi przewartościowaniami. Niemniej właściwie żadnego z ważniejszych problemów poezji drugiej połowy XX wieku nie można rozważać, abstrahując od kontekstu Holokaustu - bliskiego czy dalekiego, by jako przykład wskazać choćby kwestię zaangażowania politycznego tudzież społecznego, rozumianego różnorako. Między innymi w ten sposób - poprzez odnotowywanie cezury wojny, raczej wojny niż Zagłady - manifestuje się owa anonsowana, utarta i powszechnie przyswojona narracja o poezji. Pewną komplikację wprowadza do niej oczywiście fakt, że w wyniku takich, a nie innych okoliczności historycznych przez wiele lat trwała konsekwentna polonizacja Zagłady w dyskursie publicznym i edukacji ${ }^{18}$, na czym studia nad poezją ucierpiały chyba bardziej niż studia nad prozą.

Można bez większych wątpliwości zgodzić się z sugestią Piotra Sommera, że zrąb tej narracji wyznaczają tytuły dwóch tekstów opublikowanych tuż po

${ }_{17}$ Swoją drogą istnieje poważne ryzyko, że odwołania do znanych słów Adorna w studiach nad poezją Zagłady przybiorą swoiście rytualny charakter, niewiele właściwie wniosą do interpretacji; toteż warto wskazać na pozytywny przykład pogłębionego potraktowania prac filozofa, jakim są rozważania Aleksandry Ubertowskiej: Świadectwo - trauma - głos..., s. 130-137.

${ }_{18}$ Por. D. Krawczyńska, G. Wołowiec: Fazy i sposoby pisania o Zagładzie w literaturze polskiej. W: Literatura polska wobec Zagłady..., s. 19-27; M. GŁowiński: Wprowadzenie. W: Stosowność i forma..., s. 8-9; S. KarolaK: Doświadczenie Zagłady w literaturze polskiej. Kanon, który nie powstał. Poznań 2014. Symptomatyczny dla tego problemu jest choćby tytuł pracy zbiorowej: Literatura wobec wojny i okupacji. Studia (Red. M. GŁowiński, J. SŁawiński. Wrocław 1976), w której - co ciekawe - znajduje się artykuł Ireny MACIEJEwskiej Getto warszawskie w literaturze polskiej. Dziś podobna praktyka zwykle bierze się z potrzeby wskazywania na zazębianie się pewnych kwestii, por. Świadectwa i powroty nieludzkiego czasu. Red. J. ŚwIĘCH. Lublin 1990; J. Święch: Poeci i wojna. Studia i szkice. Warszawa 2000; Wojna. Doświadczenie i zapis: nowe źódła, problemy, metody badawcze. Red. S. BuryŁA, P. RodaK. Kraków 2006; Wojna i postpamięć. Red. Z. Majchrowski, W. OwCZARski. Gdańsk 2011. 
wojnie: tomu Ocalenie Czesława Miłosza oraz wiersza Ocalony Tadeusza Różewicza $^{19}$. Swoją drogą znamienne jest, że obaj autorzy nie doświadczyli bezpośrednio Zagłady, wszelako nie chodzi tu o wnioski płynące z gruntownej lektury bezsprzecznie przełomowych tekstów. Wiele wskazywałoby na to, że same te tytuły zyskały właściwie status kategorii, która w znacznym stopniu zaważyła na kierunkach badań, ich oddziaływanie powinno więc być przyczynkiem do namysłu nad rolą krytycznoliterackich rozpoznań i hierarchii. Co istotne, mimo uznania Holokaustu za „kamień graniczny” języka poetyckiego takie sprofilowanie refleksji poskutkowało marginalizowaniem nurtów awangardowych, w tym kontekście rozumianych zbyt wąsko. To zresztą najwyraźniej pochodna interpretacji projektu modernistycznego jako jednego z filarów myślenia, które doprowadziło do Zagłady ${ }^{20}$ - również tę diagnozę wypadałoby zniuansować przez wzgląd na twórczość powojennych modernistów. Wedle Sommera z kolei symptomatycznym skutkiem ciążenia przywołanych tytułów było wieloletnie pomijanie twórczości Jerzego Ficowskiego, wszak konsekwentnie pisał on, „że ważni są nieocaleni”"21. To także bodaj jeden z najistotniejszych, jeśli nie najistotniejszy wątek poezji ocalałych (niekiedy obecny raczej w podtekście), w tym Piotra Matywieckiego, „pogrobowca getta warszawskiego”, który przez całe swe twórcze życie podejmuje te kwestie ${ }^{22}$.

Charakteryzując dominujące ujęcia, podkreślić trzeba, że poezję Zagłady rozpatruje się w zasadzie przez pryzmat problemów swoiście naddanych, podnoszonych na gruncie opracowań historycznych, filozoficznych, socjologicznych czy psychologicznych, a nie w kategoriach immanentnych dla samej materii literackiej; pole badawcze określone jest przez zestaw tematów, niekiedy toposów, siatkę metafor ${ }^{23}$, powtarzają się pewne nazwiska i pojedyncze tytuły. Toteż można - w największym skrócie - wyróżnić kluczowe elementy tak uformowanego dyskursu. Będzie to przekonanie, że rolą poezji jest zaświadczanie o okolicznościach eksterminacji lub świadkowanie im, a z czasem stróżowanie pamięci, co jednak nie zwalnia autorów wierszy z - nierzadko akcentowanych - rozważań o sensie i konieczności tworzenia. $Z$ tym też wiąże się odnotowywane zwykle, charakterystyczne stałe napięcie między ostentacyjną rezygnacją z literackości a wyrazistym wskazywaniem na nią ${ }^{24}$. Na kanwie tego zestawu rozpoznań powstają różne warianty literaturoznawczych opowieści o stracie, żydowskim losie oraz końcu

${ }^{19}$ P. Sommer: Przewroty słów, zawroty czasu. Notatki o poezji Jerzego Ficowskiego. W: TenżE: Po stykach. Gdańsk 2005, s. 30-31.

${ }^{20}$ P. Czapliśski: Zagłada jako wyzwanie dla refleksji o literaturze..., s. 10-12.

${ }^{21}$ P. Sommer: Przewroty słów, zawroty czasu..., s. 31.

${ }^{22}$ Por. P. Matywiecki: Kamień graniczny. Warszawa 1994.

${ }^{23}$ Zob. S. DeKoven Ezrahi: The Grave in the Air: Unbound Metaphors in PostHolocaust Poetry. In: Probing the Limits of Representation. Nazism and the Final Solution. Ed. S. FriedLanDER. Cambridge, MA 1992, s. 259-277.

${ }^{24}$ Por. T. Żuкowski: Ballady o Szoa. W: Stosowność i forma..., s. 223-245. 
świata, istotne miejsce $\mathrm{w}$ dociekaniach zajmują historiozofia oraz eschatologia. Doszukując się przyczyn takiego ukierunkowania badań, dobrze wziąć pod uwagę intuicje Michała Głowińskiego, który pisał o swoiście paradygmatycznej kontynuacji poetyki skamandryckiej, ,prostej, bezpretensjonalnej, nieunikającej przedstawiania realiów i konkretów” 25 , a także podkreślał, iż „poezja polska nie miała swojego Paula Celana"26 - autora tak wybitnego, oddanego tylko temu jednemu tematowi, autora, którego twórczość stałaby się punktem odniesienia.

Rzecz oczywiście nie w tym, by deprecjonować tego rodzaju ujęcia i wynikające z nich ustalenia jako stereotypowe, wszak wydobycie i nazwanie wskazanych problemów było swego czasu zadaniem nie do pominięcia. Chodzi teraz o to, by ten tryb lektury przekroczyć, uczynić punktem odniesienia; poważnie rozważyć na płaszczyźnie studiów nad poezją Zagłady postulat oddolnego wyprowadzania teorii. Poezja właśnie jako wyjątkowo czujna obserwatorka języka - również języka pamięci - rzeczniczka autonomii i niezawisłości, wydaje się do tego zadania predestynowana ${ }^{27}$. Wprawdzie i ona nie jest wolna od sentymentalizmów czy stereotypów, ale ponieważ tkanka wiersza znosi je szczególnie źle, zostają $\mathrm{w}$ niej te procesy odsłonięte właściwie in statu nascendi. Zresztą zaobserwowanie ich winno skłaniać do pogłębionych krytycznych studiów na temat takich zjawisk w literaturze Zagłady. Ponadto warto choćby zasygnalizować, że do twórczych wniosków mogłoby prowadzić skonfrontowanie rodzimych badań $\mathrm{z}$ zagranicznymi pracami na ten temat ${ }^{28}$.

$\mathrm{W}$ artykułach opublikowanych $\mathrm{w}$ niniejszym numerze owa dominująca narracja o poezji i Zagładzie właściwie nie wybrzmi, choć trudno nie dopatrzyć się jej w podtekstach. Podobnie nazwiska najbardziej narzucających się autorów - poza jednym wyjątkiem - przywoływane są przede wszystkim kontekstowo. Te kwestie stały się jednak podwalinami otwierającej blok tematyczny rozmowy z Bożeną Shallcross, rozmowy, do podjęcia której skłoniła nas praktyka badawcza

25 M. GŁowiński: Wprowadzenie..., s. 15.

26 Tamże. Pytanie o „polskiego Celana” można również rozumieć nieco bardziej dosłownie - por. J. Roszak: Południk spotkania. Paul Celan w polskiej poezji powojennej. Poznań 2009.

${ }_{27}$ Por. inspirujące studium Tomasza Żukowskiego (Zagłada a język poetycki Tadeusza Różewicza. W: Literatura polska wobec Zagłady..., s. 141-165), który w zajmujących go wierszach autora nożyka profesora dostrzega $\mathrm{z}$ jednej strony próby terapii mowy po Holokauście, $\mathrm{z}$ drugiej - zwłaszcza w utworach późniejszych - przejawy bezkompromisowej krytyki języka. Zob. też A. Ubertowska: Świadectwo - trauma - głos..., s. 126-152.

28 Przybliża je artykuł Efraima Sichera A Poetics of the Holocaust?: Three Exemplary Poets, który znajdzie się w kolejnym numerze „Narracji o Zagładzie”. 
uczonej. Wszak w swojej uznanej monografii Rzeczy i Zagłada ${ }^{29}$ autorka wybiera kanoniczne teksty poetyckie oraz prozatorskie i interpretuje je przez pryzmat pojęć wypracowanych na gruncie zwrotu przedmiotowo-materialnego. W tym duchu - opowiadając się za zachowaniem specyfiki badań literaturoznawczych, przede wszystkim za namysłem nad kondycją języka po rozpadzie kulturowych kodów, a zarazem czerpiąc z ujęć interdyscyplinarnych - odnosi się również do zajmujących nas zagadnień, wiele uwagi poświęca konceptowi syntezy poetyckiej, kreśli inspirujący i dość szczegółowy projekt takiej pracy, wyznacza kilka nieoczywistych kręgów problemowo-tematycznych, które można by eksplorować. Ponadto zwraca uwagę na konieczność zweryfikowania kanonu, poszerzenia go o utwory do tej pory konsekwentnie pomijane. Rozmowa $\mathrm{z}$ Shallcross przynosi też ciekawe refleksje na temat metodologii, zwłaszcza, co może zrazu zaskakiwać, potencjału hermeneutyki.

Propozycje autorów i autorek poszczególnych artykułów tego numeru tworzą narrację tyleż wielogłosową, ile chóralną, jako że wszyscy oni skłaniają się ku swoiście alternatywnym ujęciom (ich ostateczny kształt, jak niektórzy chętnie odnotowują, w pewnym sensie zawdzięczają także konsultacjom $\mathrm{z}$ recenzentami tego numeru - wybitnymi znawcami o międzynarodowej renomie). Oczywiście w różnych przypadkach mają one odmienny charakter, przejawiają się w czym innym. I tak, Tomasz Żukowski w związku z wierszami Miłosza Biedny chrześcijanin patrzy na getto oraz Campo di Fiori wskazuje na możliwość - jeśli nie konieczność - rewizji kanonicznych interpretacji tych tekstów. Literaturoznawca wydobywa nieprzyswojone sensy obu utworów. Zakodowane w nich obrazy zbiorowych zachowań odsyłają wedle tej wykładni do prawdy o czynnym udziale Polaków w Zagładzie Żydów, „biedny chrześcijanin” okazuje się więc figurą centralną dla uniewinniającej narracji czy wręcz legendy zasłaniającej rzeczywistą sprawczość gapiów. To ujęcie wywołuje oczywiście pytania o inne, analogiczne przypadki wierszy - może mniej wybitnych - skrywających podobne nieodczytane treści związane $\mathrm{z}$ meandrami polskiego antysemityzmu.

Z charakteru większości artykułów zgromadzonych w niniejszym numerze wynikałoby, że najpilniejszym zadaniem rysującym się przed studiami nad poezją Holokaustu byłoby poszerzenie pola badań o nazwiska dotąd pomijane, czemu szczególnie miałyby sprzyjać nowo wypracowane kategorie (niekoniecznie stricte literaturoznawcze) oraz pytania wcześniej niestawiane poezji. Na twórczości autorek funkcjonujących na tzw. pograniczu polsko-żydowskim skupiają się Karolina Koprowska oraz Emilia Gałczyńska - obie ciekawie eksplorują czy wręcz przekraczają tę wyjściową formułę identyfikacyjną. Pierwszą z badaczek zajmuje dzieło Rejzl Żychlińskiej, której utwory jawią się jako paradygmatyczne dla kategorii miejsca urodzenia - formacyjnej i symbolicznej, swoiście ją konstytuują, czynią z niej zwornik powojennych tożsamościowych przewartościowań,

${ }^{29}$ B. Shallcross: Rzeczy i Zagłada. Kraków 2011. 
wydobywają jej ambiwalentny status, związany z doświadczeniem (niemożliwego) powrotu w rodzinne strony oraz uwikłaniem w pamięć Zagłady. Również Gałczyńska uruchamia namysł nad spacjalnymi uwarunkowaniami problemu wykorzenienia, aby przypomnieć autorkę zupełnie zapoznaną, Lolę Szereszewską. Kreśląc jej portret, badaczka wskazuje na zasadność rozszczelnienia konstruktu literatury polsko-żydowskiej, w centrum swych dociekań zaś umieszcza nieledwie profetyczny w kontekście Holokaustu, najpewniej wynikający z atmosfery ostatnich przedwojennych lat, wiersz Uchodźcom, który w opisie tytułowej kondycji okazuje się zdumiewająco uniwersalny, a wręcz aktualny. W związku $\mathrm{z}$ raczej eksterytorialnym miejscem tego utworu w dorobku Szereszewskiej wyłania się ważna - przy tym szersza, ponadjednostkowa - kwestia wtórnego naznaczenia całej twórczości Zagładą, objawia się ryzyko nadużycia, jakim byłoby projektujące czytanie jej przez pryzmat dalszych losów autorki, czego Gałczyńska się zresztą wystrzega, szuka innych dystynktywnych cech tej poezji, a wybrany wiersz poniekąd stwarza do niej dostęp.

Podobne, choć może nieco mniej spektakularne, odkrycie zapomnianego autora przynosi niebezzasadnie podzielone na dwa artykuły studium twórczości Seweryna Pollaka napisane przez Agatę Szulc-Woźniak. W pierwszym szkicu osadzonym w źródłach archiwalnych - badaczka zakreśla szeroką perspektywę, przekonująco wykazując, że poezja (w recepcji krytycznoliterackiej lokowana najniżej wśród wielorakich zatrudnień wybitnego tłumacza i eseisty) była medium, w którym ujawniał on swoją żydowską tożsamość, rejestrował doświadczenia z czasów Zagłady - tak, że mają te teksty charakter nieledwie dokumentarny; i choć pisarz sam również raczej nisko oceniał artystyczne walory swoich utworów, jednocześnie uważał je za nieodzowne w swym dorobku, jakby stanowiły pewnego rodzaju wentyl prześladujących go tematów i wspomnień. O tym, że autodiagnoza Pollaka była nadto surowa, świadczy drugi artykuł poznańskiej badaczki. To bliska konwencji close reading interpretacja wierszy o bliźniaczych tytułach Bełżec i $Z$ Bełżca zestawionych z relacją Rudolfa Redera, jednego $\mathrm{z}$ dwóch ocalałych z obozu, a także z nieprostą historią upamiętniania tego miejsca; z tej konfrontacji wynika, że teksty Pollaka odkłamują forsowaną wówczas, gdy powstały, oficjalną narrację na temat Bełżca, wyprzedzają o wiele lat utworzenie na tym terenie muzeum. Na podobnej zasadzie Wiktor Kulerski, historyk podwarszawskiego Międzylesia, rozszyfrowuje okupacyjne realia zakodowane w wierszu Juliusza Krzyżewskiego Idée fixe - odnosi się nie tylko do szczegółów topograficznych, ale odkrywa personalia do tej pory anonimowych bohaterek utworu, który nieoczekiwanie okazuje się bezprecedensowym wspomnieniem pewnej żydowskiej rodziny. W rysującej się tu konstelacji autorów i autorek nieledwie zapomnianych mieści się również zapomniane dzieło - Pamiętnik (choć formalnie dziennik intymny) Jerzego Kamila Weintrauba. Właśnie na łamach „Narracji o Zagładzie” ten tekst - w opracowaniu edytorskim Barbary Stępniak i z posłowiem Piotra Matywieckiego - ukazuje się po raz pierwszy w całości 
(w wydaniu z 1986 roku - ze względów cenzuralnych - opuszczono niektóre fragmenty). Mamy nadzieję, że jego publikacja stanie się impulsem do pogłębionych, analitycznych lektur, prowadzących do rozpoznania pozycji tego niezwykłego utworu, „więcej-niż-dokumentu”, w dorobku poety ${ }^{30}$.

Pokrewnym, także nie dość eksplorowanym na rodzimym gruncie kierunkiem badań są próby wyjścia poza poezję polską oraz żydowską, tudzież polsko-żydowską. Niewątpliwie literatura Zagłady jako z definicji wielojęzyczna potrzebuje tego rodzaju konfrontacji, co zdaje się szczególnie istotne w przypadku twórców pierwszego pokolenia i co - punktowo - poświadczają dwa artykuły zamieszczone $\mathrm{w}$ niniejszym numerze. Bartłomiej Krupa pisze o wierszu $W y$, widzowie Nelly Sachs, poetki znanej w Polsce raczej z syntetycznych omówień niż z detalicznych interpretacji jej utworów. Zresztą wybrany przez badacza tekst - osadzony w nawiedzającym wyobraźnię autorki niemieckim kodzie symbolicznym, po Zagładzie nacechowanym ambiwalentnie - kumuluje centralne dla tej twórczości sensy, okazuje się mieć swoiście metonimiczny charakter. Natomiast w drugim ze wspomnianych studiów Kinga Piotrowiak-Junkiert przedstawia nieprzekładane dotąd na język polski utwory węgierskiej pisarki Stefánii Mándy (ze względu na płeć i pochodzenie autorki nieprzyswojone w jej rodzimym kanonie), która w surrealnej prozie poetyckiej Egy halott álmaiból („Ze snów umarłej”; 1947) oraz w późniejszym tekście A szentendrei óratoriumból („Z szentendreńskiego oratorium”) wypowiedziała swoje doświadczenia obozowe. Zamysł obu utworów wynikał z potrzeby stworzenia własnego języka - na miarę i zarazem przeciw Auschwitz, był także przewrotną reakcją na ogólnospołeczną w ojczyźnie autorki skłonność do wypierania pamięci o wojennym uwikłaniu w Zagładę, skutkującą niechęcią do realistycznych narracji. Nie jest przy tym bez znaczenia, że zwłaszcza pierwszy tekst, oscylujący między grozą odrealnionej wizji a grozą wspomnień, dialogujący z dziełami awangardowych węgierskich artystów, czerpie - jak dowodzi badaczka - z filozofii „bycia Żydem” Béli Tábora, czyniącego z wykluczenia komponent tożsamości (ta koncepcja nawiasem mówiąc - może wywoływać skojarzenia z esejem Jeana Améry'ego Moje żydostwo, którego polski przekład pióra Katarzyny Kończal publikujemy w niniejszym numerze). Tak jak w przypadku Mándy - to właśnie w dyskryminacji o podłożu genderowym oraz w wymagającej surrealnej estetyce można w polskiej literaturze Holokaustu upatrywać przyczyny pomijania twórczości poetyckiej Erny Rosenstein, bohaterki artykułu Andrzeja Juchniewicza. Jej wiersze oraz obrazy badacz rozpatruje w perspektywie forensycznej, co ma bezpośredni związek z prześladującym artystkę wspomnieniem o okolicznościach zamordowania jej rodziców w czasie Zagłady, ale skutkuje także wykształceniem

${ }^{30}$ M. Piotrowiak: „Kto ten pejzaż zima niewydarzona zatrut?”. Tropy egzystencji w liryce Jerzego Kamila Weintrauba. Katowice 2009. Badacz odwołuje się do Pamiętnika zaledwie kilkakrotnie, podkreślając, że jest to źródło, któremu nie należy w pełni ufać (s. 13). 
specyficznej wrażliwości i wyobraźni, wybrzmiewającym w utworach poetki postulatem troski o kruche życie wszystkich istot ludzkich i poza-ludzkich, protestem przeciw wszelkiej spotykającej je niesprawiedliwości czy krzywdzie. Mając na uwadze różne rysujące się na tym gruncie porządki reprezentacji, Juchniewicz wypracowuje spójną ramę konceptualną, ustala niesprzeczną relację między odpowiedzialnością, z jaką wiąże się akt składania świadectwa, a surrealną poetyką. Istotne, że te rozstrzygnięcia można z powodzeniem zastosować w szerszych ujęciach twórczości problematyzującej referencjalność w kontekście Zagłady.

Podobne zależności wydobywa Daria Nowicka, pisząc o szczególnym przypadku potencjalnego oddziaływania poezji na malarstwo, a dokładniej o imaginacyjnym pokrewieństwie Louisa Aragona i Andrzeja Wróblewskiego. Chodzi o łączące obu artystów doświadczenie nieustannego obcowania z umarłymi, wpływające na status ich światów, choć wyrażone nie tylko w innych mediach, lecz przede wszystkim $\mathrm{w}$ innych estetykach. Wydaje się to znowu symptomatyczne w szerszym, sygnalizowanym tu kontekście dominacji pewnych konwencji przedstawiania, podczas gdy w okresie, o którym mowa, objawiały się różne formuły sztuki zaangażowanej, przepracowującej pamięć wojny. Cenne byłoby zastanowienie się nad ich recepcją.

Osobnym problemem-wyzwaniem, przed jakim stają współczesne studia, są wielopostaciowe odwołania do Zagłady w poezji najnowszej (punktowo wzmiankowane w artykule Martyny Dymon poświęconym jednemu tomikowi Tomasza Pietrzaka oraz w szkicu Agnieszki Czyżak o Drohobyczu Serhija Żadana). To odwołania niekoniecznie mieszczące się w znanych stylach bądź konwencjach, bywa że prowokacyjne, instrumentalne czy też popkulturowe, wymagające rewizji i poszerzenia interpretacyjnych skryptów.

Wobec genologicznego klucza przyjętego $\mathrm{w}$ niniejszym numerze ${ }^{31}$ oraz poczynionych tu wcześniej uwag warto sformułować pytanie o wyjątkowość poezji na tle szeroko rozumianej literatury bądź piśmiennictwa Zagłady, gdyż rewersem wskazanej na początku praktyki pomijania tego rodzaju twórczości w opracowaniach zdaje się wątpliwość co do zasadności wydzielania (i badania)

${ }^{31}$ Zasadność kierowania się takim podstawowym podziałem w tym kontekście swoiście legitymizują redaktorzy kompendium Literatura polska wobec Zagłady (1939-1968). Co ciekawe, autorka wstępu Dorota Krawczyńska specyfice poezji nie poświęca uwagi, obszernie pisze natomiast o prozie. 
jej jako języka osobnego, a niekiedy wręcz uprzywilejowanego. Może to sprzyjać powstrzymywaniu impulsów krytycznych wobec poszczególnych wierszy czy autorów, wspieraniu stereotypowych realizacji, kwestie estetyczne oraz aksjologiczne stają się bowiem w tym kontekście kontrowersyjne, częstokroć podporządkowywane są racjom etycznym. $\mathrm{W}$ tej perspektywie zamieszczony w epigrafie utwór Piotra Matywieckiego jawi się jako diagnoza i przestroga jednocześnie - wprawdzie odnosząca się do twórczości literackiej, ale można te obserwacje rozszerzyć również na działalność naukową.

Niewątpliwie za wyjątkowym charakterem poezji przemawia fakt, że autorzy i autorki nie tylko podejmują zadanie wyrażenia doświadczeń tak ofiar, ocalałych oraz świadków, jak i kolejnych generacji, lecz ich rozpoznania często wyprzedzają o całe dziesięciolecia dyskursywne analizy. Niestety takie prekursorskie diagnozy nie zawsze zostają odpowiednio dowartościowane, wszak nierzadko spotykamy się ze zjawiskiem instrumentalizacji pionierskich utworów, przyznawania im właściwie ornamentacyjnej funkcji w szeroko rozumianych humanistycznych studiach nad Szoa ${ }^{32}$. Równocześnie przeświadczenie o eksterytorialności poezji bywa także poznawczo, interpretacyjnie ograniczające; zamiast stanowić wyznacznik jej swoistości, może stać się argumentem sprzyjającym arbitralnej redukcji przestrzeni potencjalnego oddziaływania, prowadzić do blokowania perswazyjnej mocy. Tymczasem niewykluczone, że z namysłu nad nią w szerszej perspektywie mogłyby popłynąć twórcze impulsy konceptualne. Zatem pochodną pytania o wyjątkowość poezji jest pytanie o konieczność (zasadność?) wyraźnego wyodrębnienia metodologii jej badań.

Na koniec tych wstępnych uwag można by wysnuć więc pewien ogólniejszy wniosek czy raczej hipotezę. Otóż wiele wskazywałoby na to, że stan badań nad poezją - pewne dające się zaobserwować rozproszenie, brak spójnych projektów lekturowych - jest symptomatyczny dla peryferyjnego miejsca, jakie literaturoznawstwo zajmuje dziś w studiach nad Zagładą ${ }^{33}$, gdy coraz wyraźniej wychylając się w stronę orientacji kulturowych, poważnie ryzykuje ono utratę swoistości. Bez wątpienia oscylacja między tym, co specyficzne dla języków poetyckich,

${ }^{32}$ To - jak sądzę, nieodosobniony - przypadek wiersza Jerzego Ficowskiego pt. Milczenie ziemi (z tomu Moje strony świata. Kraków 1957), chętnie przywoływanego w pracach historyków środowiskowych (np. Mikołaja SmyкоwsKiego: Eksterminacja przyrody w Lesie Rzuchowskim. „Teksty Drugie” 2017, nr 2, s. 73-74 czy Jacka MaŁczyńskiego: Krajobrazy Zagłady. Perspektywa historii środowiskowej. Warszawa 2018, s. 187-188) jako kontekstowa wzmianka. Tymczasem to poeta wprowadza refleksję (w tym samym zbiorku znajduje się jeszcze równie ważny cykl $W$ imię ziemi) dostrzeżoną na polskim gruncie po ponad półwieczu, gdy wypracowano narzędzia dyskursywne zdolne uchwycić te sensy. Por. M. Kobielska: Nastrajanie pamięci. Artykulacja doświadczenia w poezji Jerzego Ficowskiego. Kraków 2010; M. BARon: Grzebanie grzebania. Grabarz $i$ archeolog w twórczości Jerzego Ficowskiego. Katowice 2014.

${ }^{33}$ Co może świadczyłoby o zmianie, jaka zaszła od czasu optymistycznych diagnoz postawionych przez Przemysława Czaplińskiego (Zagłada jako wyzwanie dla refleksji o literaturze..., s. 21). 
a tym, co łączy je z innymi dyskursami, zdaje się konieczna dla rozwoju refleksji krytycznej, pozwala uniknąć zamknięcia we wsobnych konceptualizacjach. Niemniej warto równocześnie ponawiać pytanie o różnicę, jaką wprowadza medium poezji, cechujące się wysokim stopniem dystynktywności, często stanowiące przecież alternatywę dla narracji jako takiej, więc w przeciwieństwie do prozy czy opowieści dokumentarnych mniej podatne na ujednolicające formuły i właśnie dzięki temu umożliwiające wydobycie odrębności literaturoznawczych ujęć. Dlatego upominając się o status poezji, zabiegamy o to, by na nowo zdefiniować jej rolę w tym obszarze, wskazać na możliwość potraktowania poezji jako źródła komplementarnego wobec tradycyjnych źródeł historycznych, a nade wszystko szkoły języka (także naukowego).

Trzeba jeszcze podkreślić, że zamysł niniejszego, poświęconego poezji numeru „Narracji o Zagładzie” po części wynika z kwestii wcześniej podnoszonych na łamach naszego rocznika - podpowiedzi, jakie znalazły się w artykułach publikowanych w ubiegłych latach. Znaczy to, że kilkanaście studiów zebranych $\mathrm{w}$ bloku tematycznym uznajemy też za ważny bilans dotychczasowych prac, który chcielibyśmy dopełniać rozprawami ogłaszanymi w kolejnych numerach, aby, być może, w pewnym momencie wrócić do postawionych tu pytań o poezję Zagłady, weryfikując sformułowane postulaty i diagnozy bądź znajdując dla nich potwierdzenie.

Anita Jarzyna

(D) http://orcid.org/0000-0001-7527-6085 


\section{Poezja i Zagłada}

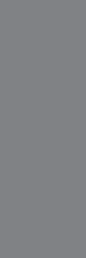

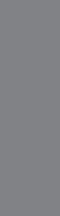


